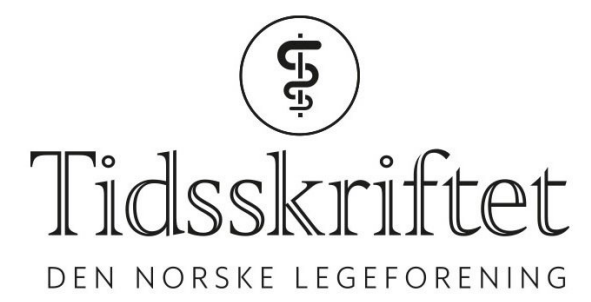

\title{
Bidrar overdiagnostikk til høye melanomtall?
}

KOMMENTAR

\section{TRUDE EID ROBSAHM}

E-post: trude.eid.robsahm@kreftregisteret.no Trude Eid Robsahm er forsker ved Kreftregisteret. Ingen oppgitte interessekonflikter.

\section{LILL TOVE NORVANG NILSEN}

Lill Tove Norvang Nilsen er forsker ved Statens Strålevern. Ingen oppgitte interessekonflikter.

\section{INGRID ROSCHER}

Ingrid Roscher er overlege ved Seksjon for hudsykdommer, Oslo universitetssykehus. Ingen oppgitte interessekonflikter.

\section{PETTER GJERSVIK}

Petter Gjersvik er førsteamanuensis ved Institutt for klinisk medisin, Universitetet i Oslo Ingen oppgitte interessekonflikter.

Ivar $\varnothing \emptyset n b \emptyset$ Kristiansen og medarbeidere fremsetter en hypotese om at overdiagnostikk og screening kan ha bidratt til den sterke økningen i forekomst av kutant melanom i Norge de siste tiårene, fordi det kan finnes et «stille reservoar» av kreftvev (1). Med overdiagnostikk mener de at «man ved intensivert diagnostikk, typisk screening, oppdager kreftvev eller kreftsvulster som ikke ville ha gitt kliniske symptomer i pasientens levetid». De mener det ikke finnes god dokumentasjon for at befolkningens eksponering for ultrafiolette (UV) stråler har økt. I tillegg mener de at økt informasjon om solbeskyttelse burde ha medført nedgang i forekomsten.

Befolkningens eksponering for UV-bestråling har økt betydelig i løpet av de siste tiårene. Her tar Kristiansen og medarbeidere feil. Folk reiser oftere til Syden, har lengre ferier enn før og oppholder seg mer utendørs enn folk i land lengre sør i Europa $(2,3)$. Slik atferd øker risikoen for solforbrenning, som er den viktigste risikofaktoren for melanom (4). Det er også godt dokumentert at informasjon om sunne solvaner, inkludert bruk av solkrem, ofte ikke følges (5).

Organisert screening for melanom skjer ikke i Norge og er verken gjennomførbart eller effektivt. Norske hudleger, i samarbeid med Kreftforeningen, arrangerte i perioden 2014-17 en årlig hudsjekkdag for å gi befolkningen informasjon om sunne solvaner og faresignaler for melanom - ikke for å påvise flere melanomer. Vi kan ikke utelukke at slike kampanjer har ført til mer føflekkfjerning. Forfatterne fant at antall føflekker som ble fjernet, steg med 
$83 \%$ fra 2006 til 2015, som kan indikere økt diagnostisk intensitet. Men de fant ingen sammenheng mellom fylkesvis variasjon i antall føflekkfjerninger og melanomforekomst. Dette taler imot overdiagnostikk som følge av hyppig føflekkfjerning. Hvorvidt det finnes et «stille reservoar» av melanomer, slik det synes å gjøre for bl.a. prostatakreft, er vanskelig å dokumentere vitenskapelig.

Norge har høyeste dødelighet av melanom i Europa. Prognosen ved melanom er knyttet til tumortykkelse. Tall fra Norsk kvalitetsregister for føflekkreft viser at etter 2010 har gjennomsnittlig melanomtykkelse vært stabil, og nordmenn har tykkere melanomer i forhold til sammenlignbare land. Vi er ikke gode nok til å diagnostisere melanomer tidlig. Melanom er potensielt dødelig og kan i tidlig fase helbredes med enkel kirurgi. Vi utelukker ikke en glidning i histologiske kriterier for melanom over tid, men hypotesen om mulig overdiagnostikk bør ikke bygge på misforståelser om UV-eksponering, føflekkfjerning og bruk av solkrem. Faresignaler for melanom må bli bedre kjent, og vi trenger bedre verktøy for å skille melanom fra ufarlige hudforandringer.

\section{LITTERATUR:}

1. Kristiansen IS, Bugge C, Førde OH. Bidrar overdiagnostikk til høye melanomtall? Tidsskr Nor Legeforen 2018; 138: doi: 10.4045/tidsskr.17.060o. [CrossRef]

2. Granseth T. red. Norsk turisme. Oslo/Kongsvinger: Statistisk sentralbyrå, 2011. https://www.ssb.no/transport-og-reiseliv/artikler-og-publikasjoner/_attachment/64966?_ts=136eз8зe2 88 (28.6.2018).

3. Nilsen LTN, Johnsen B, Komperød M et al. UV-eksponering av den norske befolkningen. Fra sol og solarier. Strålevern Rapport 2015: 7. Østerås: Statens strålevern, 2015. http://docplayer.me/386199-Uv-eksponering-av-den-norske-befolkningen-fra-sol-og-solarier.html (28.6.2018).

4. Berwick M, Buller DB, Cust A et al. Melanoma epidemiology and prevention. Cancer Treat Res 2016; 167: 17-49. [PubMed][CrossRef]

5. Ghiasvand R, Weiderpass E, Green AC et al. Sunscreen use and subsequent melanoma risk: a population-based cohort study. J Clin Oncol 2016;34:3976 - 83. [PubMed][CrossRef]

Publisert: 20. august 2018. Tidsskr Nor Legeforen. DOI: 10.4045/tidsskr.18.0547

(C) Tidsskrift for Den norske legeforening 2020. Lastet ned fra tidsskriftet.no 